\title{
新潟県において妻面外側に幣串 を釘止する事例の調査
}

\section{RESEARCH ON THE CASE TO NAIL HEIGUSHI AT OUTSIDE OF GABLE IN NIIGATA PREF.}

\section{平山育男— *1 梅嶋 修— $* 2$ \\ 西澤哉子 $* 3$}

キーワード

幣串, 妻面, 上棟式, 新潟県

Keywords:

Heigushi, Gable, Zyotousiki, Niigata pref.

\section{Ikuo HIRAYAMA — $* 1$ \\ Kanako NISHIZAWA - * 3}

Osamu UMEJIMA — $* 2$

We confirmed nailed heigushi at the ridge pole both ends. When roof was over, most of heigushi nailed again in a hut bunch near gable, but several heigushi were nailed at outside gable.

\section{1. はじめに}

新潟県中越地方を中心とする歴史的建造物の悉皆調査において、 著者らは建物妻面外側に直接、幣串が釘止される事例（以後 “外幣 串”と称する）を数々見いだし、これらを地域ごとに整理して報告 を行っている ${ }^{1)}$ が、管見の限り、外幣串についてのまとまった事例 報告は確認していない。

加えて著者らは施工する側の大工職一対し、外幣串に関するアン ケート調查を実施し、その実施経緯を明らかにしてきている ${ }^{2)}$ 。

そこで本稿では外幣串の実態について、建物内外に残る幣串の調 查、大工職に対するアンケート調査結果の両面から、この事例につ いて考察を進めるものである。

\section{2. 新潟県において確認された妻面外側に幣串を釘止する事例} 著者らが建物の妻面外側に幣串を配する事例を最初に確認したの

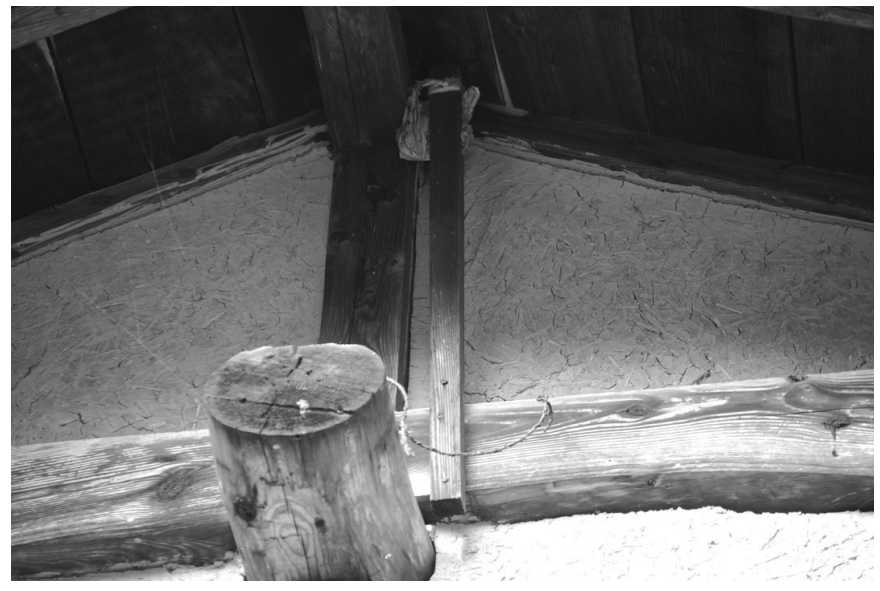

写真 1 長岡市和島地域 HO 家住宅倉庫
は、平成 19(2007) 年における長岡市歴史的建造物調査において栃尾 地域を訪れた際である。この事例は切妻造妻入形式の町家正面下屋 上に幣串 3 本を台に固定して木槌などとともに配置するもので、後 の聞き取り調查などから当該の住宅は大工職の住居であることを知 った。つまり、この事例においては幣串が妻正面外側に配されるも のの、妻面に直接打ち付けられる外幣串の形式ではなかった。

以後の調查においては妻面外側に幣串の配されることのあること を念頭に置きながら調查を実施した結果、平成 21 (2009) 年における 三条市中心市街地における町並み調查において、幣串を建物妻面外 側に直接釘止する外幣串の事例を確認するに至った。この調查では 対象物件 1,542 件に対して外幣串 5 件、調查地に隣接した地点で 1 件、合計 6 件 (いずれも主屋)の事例を確認した ${ }^{3)}$ 。

以後、新潟県中越地方における調查では、同年における長岡市歴 史的建造物調查において長岡市寺泊地域で 2 件 (主屋 1 件、納屋 1

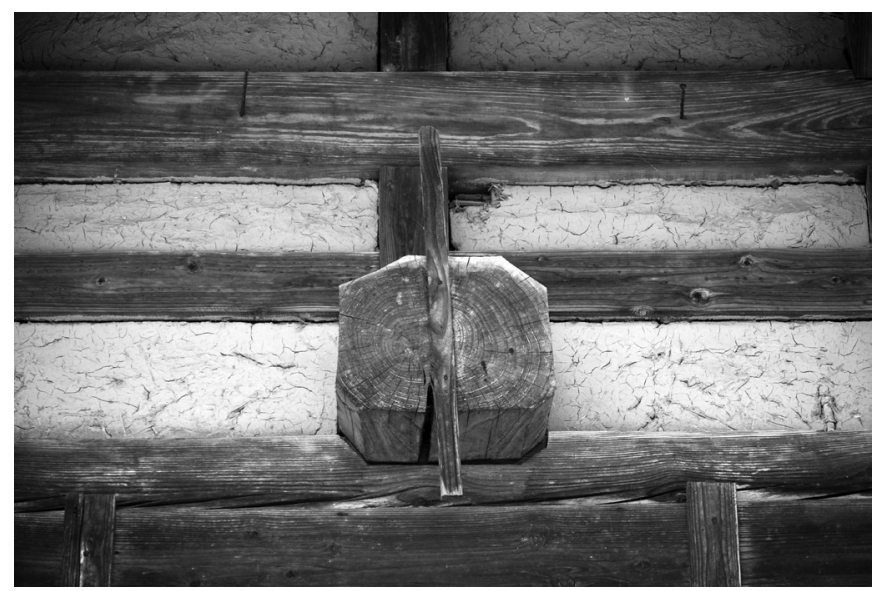

写真 2 長岡市中之島地域 KN 家住宅倉庫
長岡造形大学 教授

（テ 940-2088 長岡市千秋 4-197）

(森グリーンシグマ

長岡造形大学デザイン研究開発センター 研究員
Prof., Nagaoka Institute of Design

Member of Green-sigma Co., Ltd.

Researcher of Design Research \& Development Center, Nagaoka Institute of Design 
件)、与板地域で 2 件 (いずれも主屋)の外幣串を確認した。更に、平 成 22 (2010) 年における長岡市和島、中之島地域における長岡市歴史 的建造物調查では、和島地域で 17 件 (寺院 2 件、神社 1 件、納屋. 倉庫 6 件、主屋 8 件)、中之島地域で 15 件（主屋 13 件、倉庫 2 件） の外幣串を確認したが、この内、和島地域の 3 件、中之島地域の 6 件が両妻面外側に幣串を釘止するものであった ${ }^{4)}$ 。また、平成 23 (2011) 年における長岡市三島、川口地域における長岡市歴史的建 造物調查では三島地域で 5 件、川口地域では 3 件の外幣串を確認し たが、両面の外幣串は確認されなかった ${ }^{5)}$ 。

一方、平成 22 (2010) 年の柏崎市南部における民家の悉皆調查にお いては妻面外側に幣串などを有する建物 16 件を確認している ${ }^{6)}$ 。

なお、上記以外でも筆者らは長岡市山田、福住、九川や新潟市江 南区沢海、阿賀野市山口町においても外幣串の事例を確認している。

\section{3. 新潟県内の大工職に対するアンケート調査}

このように、外幣串の事例は新潟県中越地方を中心としてかなり 広範な地域において存在することを把握した。そのため筆者らはこ の事例が新潟県内において、どれ程の広がりを有するのか確認する ため、新潟県内における大工職に対してアンケート調查を実施し、 この事例の実態を調查することとした。

\section{1 アンケートの方法}

先ず、新潟県における大工職は NTT の職業別電話番号簿によって 180 件を抽出した。これら全件に対して“「幣串を建物の妻面に打ち つける」ことの実態調查”として、新潟県中越地方において建物の 外側妻面に幣串を打ちつけることがある旨を、写真とともに説明し た依頼書を作成し、アンケート項目は返信葉書に印刷した。アンケ 一トの項目は葉書表面に回答者の名前、年齢、会社名、会社所在地、 電話番号、葉書裏面に幣串を建物の妻面に打ち付ける習慣の有無、 ある場合の時期・建物、その他、の事項を印刷し、依頼書とアンケ 一トを印刷した葉書を郵送した。対象者への郵送は平成 23 (2011) 年 11 月末に行い、平成 24 (2012) 年 1 月 31 日までの返信をお願いした。

\section{2 アンケート調査の回収}

アンケートの返信は 180 件中 22 件、返答率は $12 \%$ であった。返 信 22 件の内容中、回答者の年齢、会社所在地、幣串を建物の妻面に 打ち付ける習慣の有無、ある場合の時期・建物、その他、の項目に ついて表 1 にまとめた。

\section{3 アンケート調査の結果}

アンケートの返信によると、幣串を建物の妻面に打ち付けること を行ったことがある、との返信は 4 件あり、これらには確認のため 再度、電話にて聞き取り調查を実施した。以下が電話による聞き取 りの内容で、以下の○囲み数字は表 1 の「番号」欄に対応する。

(2)阿賀野市の事例では、上棟式の際に 3 本幣串を作成し、式後に 2 本を両妻に打ちつけるものの、屋根を莫く際に小屋内一幣串は移 動させるとのことであった。

(15)新潟市江南区、211三条市の事例も聞き取りによれば同様で、屋 根莫きの際に幣串は小屋内へ移動させるとのことであった。

また、(19新発田市の事例はその他欄に、幣串を作ることのみの記 載で、電話による聞き取りで、両妻面外側に幣串を打ち付けること はないとのことであった。

なお、(20柏崎市の事例では、自分では妻面外側に幣串を打ち付け

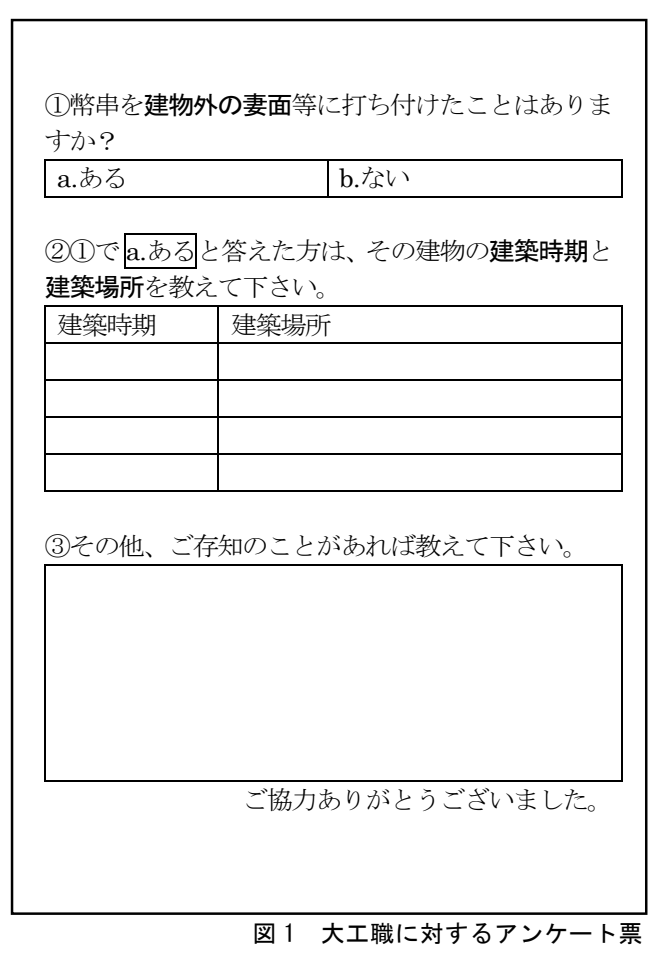

たことはないものの、かつて祖父の家の妻面外側には幣串が打ち付 けてあったと言う。

つまり、新潟県内おいて実施した“幣串を建物の妻面に打ちつけ る」ことの実態調査” から、幣串を上棟式後、妻面に打ち付ける事 例は存在するものの、いずれも屋根莫時に小屋内一移動させたこと が明らかとなった。なお、8 才までの回答者で、幣串を建物妻面に 打ち付けたままにしておくとする回答者はいなかったこととなる。

\section{4. 新潟県において幣串を妻面に打ち付ける事例について}

アンケート調査において、幣串を妻面外側に打ち付けたままにす ると回答した大工職はいなかったが、文献や実際の住宅工事におい て、幣串はどのように扱われているのであろうか。以下では、新潟 県中越、下越地方を対象とする文献（市史）と住宅から発見された 幣串の状態について考察を加えたい。

\section{1 新潟県内において妻面に幣串を配する事例の報告}

新潟県における市史類において、妻面に幣串を打ち付ける事例を 記すものは管見の限り以下の 3 点である。

(1)三条市史 資料編第 8 巻民俗 ${ }^{7)}$

三条市内における事例として、建前に際し

棟木の両端に打ち付ける幣（大工が造る）を二本用意する とされる。

(2)燕市史 民俗・社会・文化財編 ${ }^{8)}$

隣接する燕市でも上棟式において

棟梁が準備するものに、幣束を切ると言って、三本の御幣《中 略》を準備した。《中略》棟梁の祈䘠で式が始まる。途中にて、 棟梁の合図で、二本の御幣を二人の弟子が、棟木の両妻に打ち 付ける

とする記述を市史に確認することができる。

(3)新津市史 資料編 6 民俗・文化財 ${ }^{9)}$ 


\begin{tabular}{|c|c|c|c|c|c|c|c|c|}
\hline 番号 & 名前 & 年齢 & 会社所在地 & \multicolumn{2}{|c|}{ 有無 } & 建築時期 & 建築場所 & その他 \\
\hline (1) & H.I. & 72 & & & ない & & & 屋根裏の中央位の棟木の玄関側の方向に打つ \\
\hline (2) & S.S. & 70 & 阿賀野市保田 & ある & & 平成13 & 阿賀野市保田 & $\begin{array}{l}\text { 住宅新築上棟式 3本組の幣串上棟式用 その他2本両方の妻に取り付ける } \\
\text { [電話にて聞き取り] } \\
\text { 祭壇に挙げる3本の内、1本は持ち帰り、自分で日付や場所を記入する。自分 } \\
\text { でも3本くらい持っている。残り2本は両妻に打ち付け、瓦を引くときに小屋の } \\
\text { 中に打ち替える。 }\end{array}$ \\
\hline (3) & S.S. & 65 & 小千谷市三仏生 & & ない & & & $\begin{array}{l}\text { 上棟の時、南側か東側の棟木に打ちつけ、屋根工事の時はずし家の中の棟 } \\
\text { 束に打ちつけておきます。 }\end{array}$ \\
\hline (4) & Y.H. & 76 & 佐渡市徳和 & & ない & & & \\
\hline (5) & T.T. & 70 & & & ない & & & $\begin{array}{l}\text { 棟梁の祈䘠で式が始まる時に3本の幣束台を作り3枚の幣束紙を切って上棟 } \\
\text { 式に打ちつけ。 }\end{array}$ \\
\hline (6) & M.N. & 76 & 弥彦村弥彦 & & & & & $\begin{array}{l}\text { 実は大エの夫はもういません。私(妻) は何も分かりませんので、お役に立て } \\
\text { なくて本当にすみません。 }\end{array}$ \\
\hline (7) & H.M. & 75 & 阿賀町津川 & & ない & & & \\
\hline (8) & M.W. & 68 & 村上市板屋越 & & ない & & & 私共の地区では棟札と一緒に棟木の側面又は棟束に打ちつけておきます。 \\
\hline (9) & - & & 新潟市中央区関屋 & & ない & & & \\
\hline (10) & K.F. & 55 & 上越市中郷区藤沢 & & ない & & & \\
\hline (11) & K.I. & 57 & 妙高市工団町 & & ない & & & $\begin{array}{l}\text { こちらの方面での風習はなかったようです。年配のベテラン大エにも確認しま } \\
\text { したが、同様の返事でした。 }\end{array}$ \\
\hline (12) & S.K. & 57 & 新潟市南区白根水道町 & & ない & & & $\begin{array}{l}\text { 私が建築にたづさわってからは上棟後小屋裏両妻に幣束を打ちつけていま } \\
\text { す。 }\end{array}$ \\
\hline (13) & S.K. & 55 & 小千谷市大字塩殿甲 & & ない & & & 私は幣串は妻の内側の棟束に打ちつける \\
\hline (14) & I.S. & & 新潟市秋葉区新町 & & ない & & & \\
\hline (15) & T.S. & 61 & 新潟市江南区城所 & ある & & 昭和 50 前後 & 阿賀野市深堀 & 最近依頼がなくなり淋しい限りです。伝統を受けつぐ人々がいなくなっていま \\
\hline & & & & & & 昭和49年頃 & 横越小杉 & $\begin{array}{l}\text { す。電話にて聞き取り] } \\
\text { 建前で両妻面外に打ち付け、瓦莫をするときに小屋中へ打ち直す。 }\end{array}$ \\
\hline (16) & Y.T. & 61 & 十日町市寅甲 & & ない & & & \\
\hline (17) & H.Y. & 54 & 上越市上中田 & & ない & & & $\begin{array}{l}\text { 上越地方では今まで見たことがありません。高田、直江津、新井が地区です } \\
\text { が、糸魚川地方はあまり行かないのでわかりません。 }\end{array}$ \\
\hline (18) & Y.Y. & 57 & 系魚川市滝川原 & & ない & & & 上棟式の時はありますが完成後は棟木に打ちつける \\
\hline (19) & M.S. & 82 & 新発田市真野原外 & ある & & & & $\begin{array}{l}\text { 創業昭和28年四月より、現社も小屋、住宅、寺社には建物中には幣束は1本 } \\
\text { 打つて有ります。下越地方は色々です。2本打ち所〜1本打ち所。私は親方よ } \\
\text { り家の中に1本打つことは教えられた話はお話は大分ん有ります。建物に対し } \\
\text { ても色々有ります。 } \\
\text { 建主に頼まれた場合、棟札を付ける。寺社には全分棟札は取り付ける。 } \\
\text { [電話にて聞き取り]坂上ひろき(甥) 48才 } \\
\text { 当地方で幣串を建物妻面に打ちつけることはない。 }\end{array}$ \\
\hline (20) & H.T. & 64 & 柏崎市比角 & & ない & & & $\begin{array}{l}\text { 祖父の家にありました。昭和初期の建築です。(現在解体)柏崎市住吉町 (現 } \\
\text { 西本町1丁目) } \\
\text { [電話にて聞き取り] } \\
\text { 祖父の家は鍛治屋をやっていた。その妻面に幣串があったようだ。やや小振 } \\
\text { りのものであった。 }\end{array}$ \\
\hline (21) & M.S. & 68 & 三条市泉新田 & & ない & & & $\begin{array}{l}\text { 記載の通り棟木の両方に幣束を打ちつける。三条地区は大分前からやって } \\
\text { いる。近年は神社、寺はもちろん木造建築においては大き建物でしかやっ } \\
\text { ていない。上棟式の時になる。 } \\
\text { [電話にて聞き取り] } \\
\text { 上棟式では棟中央と両妻に幣串を立てる。屋根瓦を荣く時に小屋組内部に移 } \\
\text { 動させたり、持ち帰り、次回の式に用いる。 }\end{array}$ \\
\hline (22) & M.S. & 50 & 見附市本所 & & ない & & & \\
\hline
\end{tabular}

凡例「名前」欄：頭文字をアルファベットで示した。「住所」欄：市町村名と町名までとした。「その他」欄：アンケートにおける(3)の記載をそのまま載せ、更 に後の電話による聞き取りの内容を［電話にて聞き取り］として示した。

表 2 新潟県中越地域の住宅建築における幣串・棟札の発見場所

\begin{tabular}{|c|c|c|c|c|c|c|c|c|c|}
\hline 番号 & 市町村 & 町名 & 住宅名 & 建物名 & 建物の形式 & 建築年代 & 幣串/棟札 & 発見場所 & 不要の釘穴 \\
\hline 1 & 三条市 & 本町 & つるが屋 & 主屋 & 入母屋造栈瓦葺 & 大正時代末頃 & 幣串 & 正面妻内直近の小屋束外側面 & \\
\hline 2 & 長岡市 & 袋町 & 星野家住宅 & 主屋 & 切妻造栈瓦荣 & 大正時代末頃 & 幣串 & 棟木中央下 & \\
\hline 3 & 三条市 & 本町 & かじまちの家 & 土蔵 & 切妻造栈瓦荣 & 昭和2(1927)年 & 棟札 & 中央真束正面 & \\
\hline 4 & 三条市 & 仲之町 & 新光屋 & 主屋 & 入母屋造栈瓦莫 & 昭和3(1928)年 & 幣串 & 正面妻面小屋内(剥離) & 下部に2個所 \\
\hline 5 & 三条市 & 元町 & 旧若松 & 別棟 & 入母屋造栈瓦葺 & 昭和戦前期 & 幣串 & 両妻面小屋内直近の小屋束外側面 & \\
\hline 6 & 三条市 & 本町 & 山田美術 & 主屋 & 入母屋造栈瓦莫 & 昭和9(1934)年 & 木札 & 背面小屋内妻梁 & \\
\hline 7 & 三条市 & 本町 & かじまちの家 & 離れ座敷 & 入母屋造栈瓦葺 & 昭和15(1940)年 & 紙札 & 中央真束正面 & \\
\hline 8 & 三条市 & 明神町 & 外山虎松商店 & 主屋 & 入母屋造栈瓦葺 & 昭和27(1952)年 & 幣串 & 背面小屋内妻面小屋束内側面 & 下部に2個所 \\
\hline 9 & 三条市 & 元町 & 旧若松 & 主屋大広間 & 入母屋造栈瓦莫 & 昭和35(1960)年頃増築 & 幣串 & 南妻小屋内直近の小屋束外側面 & \\
\hline
\end{tabular}

備考 事例4では、釘は残っていたが、束からは剥がれ、小屋内妻面から発見された。

事例6では、建築年代、施主名などの記された木札が主屋背面小屋内の妻梁に洋釷止めされていた。 


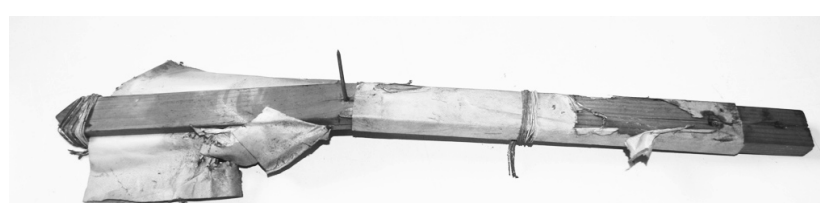

写真 3 三条市外山虎松商店の幣串

この幣串は、中央向かって左寄りの洋釘で小屋組内の妻棟束内側に止めら れていた。なお、向かって右側となる幣串下部には使われていない洋釷穴 2 箇所を確認することができる。

新潟市に合併された新津市の市史にも類似の記載が見られた。つ まり上棟式においては

棟梁が祝詞を読み上げて祈願する。棟梁が「ヨーイ」と掛声を かけると、二人の大工の弟子が、柄に白紙をつけ紅白の水引を 巻いた木槌か金槌で屋根の両端の棟木をトン・トン・トンと三 回調子を合わせて吒く。そして、棟梁はまた祝詞を読み上げる。 《中略》その後、屋根の上に昇った者たちでお神酒を酌み交わ し、二本の御幣を両妻の棟木付近に打ちつける。 とする。

つまり、以上の記載から新潟県の中越から下越地方では、上棟式 において幣串を両妻に掲げる風習が広く見られたことが分かるので ある。但し、ここでは幣串を上棟式に際して “棟木の両端”や ‘棟 木の両妻に打ち付ける”ものの、幣串を建物竣工後もそのままにす るのかは明らかでない。

\section{2 新潟県内の住宅において幣串を配する場所と方法}

このように新潟県内各地における市史の記述から上棟式に際して 幣串を棟木両妻に打ち付ける慣習があったことは明らかで、アンケ ートでもこれに合致する回答を得ることができた。但し、アンケー トによれば妻面に打たれた幣串は屋根を莫く段階で小屋内に打ち直 されるとする回答が複数寄せられた。それでは打ち直される幣串は 小屋内部のどこに打ち直されるのであろうか。

表 2 はその疑問を考えるため、筆者らが近年、長岡及び三条地域 において実施した住宅についての建築調查を通して見出した幣串の 打ち付け場所をまとめたものである。これによると 9 例中 6 例まで が建物妻面寄りの小屋束に幣串が釷止されていることが分かる。し かも、写真 3 に示したように幣串には使用されていない釷穴も確認 することができた。つまり、この使われない釘穴を用いて上棟式に 際し幣串は “棟木の両端” などに打ち付けられ、その後の屋根莫き に際し、直近となる妻面小屋内の小屋束などに幣串は打ち直された と推察することができるのである。

また、写真 1 に示した長岡市和島地域における外幣串の事例では、 幣串下側 2 本の洋釘で幣串は妻梁に固定されるが、その上に 1 本、 不要の洋釘が確認される。つまり、外幣串として確認される事例で も、上棟式に際して一度、幣串は棟木両妻などに固定された後、妻 面外に打ち直され、外幣串として確認されることがこの事例からも 確認できるのである。

\section{5.まとめ}

新潟県においては中越地方の長岡市、三条市、柏崎市や下越地方 などの歴史的建造物では建物妻面外側に幣串を釘止する外幣串の事 例が確認された。
一方、新潟県の大工職に対して外幣串の実施を問うと、幣串を上 棟式後、妻面に打ち付ける慣習は確認されたが、いずれも屋根莫時、 小屋内一移動させるとし、82才までの回答者から幣串を建物妻面外 側に打ち付けたままにしておくとの回答はなかった。

ところで、三条市、長岡市の住宅調査において小屋内から発見さ れた幣串は過半が妻面寄りの小屋束側面に打ち付けられ、その複数 例からは使われていない釷穴を発見し、幣串の打ち直しを確認した。

即ち、新潟県中越、下越地方の上棟式において幣串を棟木両妻付 近に釘止する慣習のあったことが市史の記述や大工職に対するアン ケート調查から判明した。そして棟木妻付近に釷止された幣串の多 くは屋根莫時に小屋内妻面付近の小屋束などに打ち替えられるが、 あるものは妻面外側に釘止され、“外幣串”として確認されるのであ ろう。

今後は、より広範な実地踏查を行い外幣串の分布を明らかにする ともに、幣串の打ち替えの事由についても考察を加える予定である。

なお、本調查は平成23 (2011) 年度科学研究費補助金 (若手研究 (B) ) 22760491 の助成 (代表：梅嶋修)による研究成果の一部である。

注

1)これまで、外幣串について筆者らは以下の報告を行っている。 (1)西澤、平山：三条市中心市街地における幣串を妻面に有する町家の調查 研究 三条市中心市街地の町と町家の調查研究 その 4、日本建築学会北陸 支部研究報告集 53、429 430 頁、平成 22 (2010). 7

(2)平山、西澤：長岡市和島・中之島地域において幣串を妻面に有する歴史 的建造物について：長岡市歴史的建造物悉皆調查 (10)、日本建築学会北陸 支部研究報告集 (54)，579-580 頁, 平成 23(2011). 7

(3)梅嶋、西澤 : 柏崎市歷史的建造物調查 (4) : 柏崎市南部において妻面に 幣串を有する歷史的建造物、日本建築学会北陸支部研究報告集 (54), 513-514 頁, 平成 23(2011).7

(4)西澤、平山：長岡市三島・川口地域において幣串を妻面に有する歷史的 建造物について、長岡市歴史的建造物悉皆調查 (14)、日本建築学会北陸支 部研究報告集 (55), 平成 24 (2012). 7

2) 平山、梅嶋、西澤 : 新潟県において幣串を妻面外側に打ち付ける事例の実 態調查報告、日本建築学会北陸支部研究報告集 (55), 平成 24 (2012). 7

3）注 1) (1)参照。なお、三条市中心市街地においては調查対象地外において、 これ以外の事例も複数例確認している。

4) 注 1) (2)参照

5) 注 1) (4)参照

6) 注 1) (3)参照

7) 三条市史編修委員会: 三条市史資料編第 8 巻民俗、444 頁、昭和 57 (1982). 3

8）燕市：燕市史民俗・社会・文化財編、158 頁、平成 $2 （ 1990 ） .3$

9）新津市：新津市史資料編 6 民俗・文化財、227 頁、平成 3 (1991). 3

[2012 年 6 月 19 日原稿受理 2012 年 9 月 28 日採用決定 $]$ 